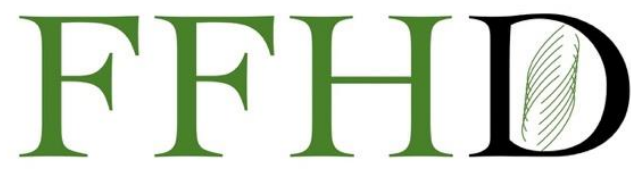

Functional Foods in Health and Disease

\title{
Anti-proliferative activity of yerba mate (Ilex paraguariensis) aqueous extracts on human colorectal cancer cell lines
}

\section{Ali Jason Saleh ${ }^{1}$, Leen Othman ${ }^{2}$, Michel Elchoueiry ${ }^{1}$, Rita Ghanem ${ }^{1}$, Samer Bazzi ${ }^{1}$, Marwan El- Sabban $^{3^{*}}$, Roula M. Abdel-Massih ${ }^{1^{*}}$}

${ }^{1}$ Department of Biology, Faculty of Arts and Sciences, University of Balamand, Koura, Lebanon; ${ }^{2}$ Department of Biomedical Sciences, Faculty of Medicine, University of Balamand, Koura, Lebanon; ${ }^{3}$ Department of Anatomy, Cell Biology and Physiological Sciences, Faculty of Medicine, American University of Beirut, Beirut, Lebanon.

*Corresponding Authors: ${ }^{1}$ Roula M. Abdel-Massih, Department of Biology, Faculty of Arts and Sciences, University of Balamand, Lebanon; ${ }^{3}$ Marwan El-Sabban, Department of Anatomy, Cell Biology and Physiological Sciences, Faculty of Medicine, American University of Beirut, Beirut, Lebanon.

Submission Date: August $5^{\text {th }}, 2021$; Acceptance Date: September $7^{\text {th }}, 2021$; Publication Date: October $5^{\text {th }}, 2021$

Please cite this as: Saleh A.J., Othman L., Elchoueiry M., Ghanem R., Bazzi S., El-Sabban M., Abdel-Massih R.M. Antiproliferative activity of yerba mate (Ilex paraguariensis) aqueous extracts on human colorectal cancer cell lines. Functional Foods in Health and Disease 2021. 11(10): 499-511. DOI: https://www.doi.org/10.31989/ffhd.v11i10.828

\begin{abstract}
Background: Yerba mate, a popular, tealike beverage prepared from the dried leaves of llex paraguariensis, is widely consumed, and has several reported health benefits. Compared with other herbal teas, the effect of yerba mate on human cells in the context of cancer has not been extensively studied. The method of extraction of bioactive compounds from the yerba mate leaves plays an important role in its effect on cancer cells.
\end{abstract}

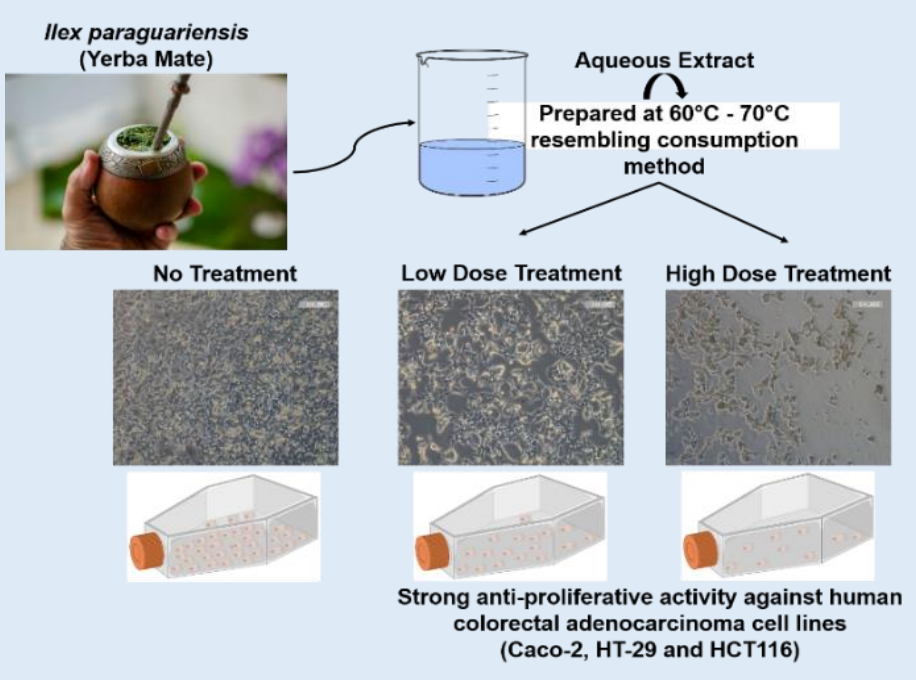

Methods: In this study we assessed the viability, anti-proliferative, and apoptotic effect of the aqueous yerba mate extract, prepared using the same conditions employed for consumption, on different human colorectal cancer cell lines (Caco-2, HT-29, and HCT116) and on the non-tumorigenic human colon epithelial cell line (NCM460). 
Results: Cytotoxicity of aqueous yerba mate extract was studied and a dose-dependent decrease in viability was observed in all the tested cell lines. At 24 hrs., viability decreased to 19.7\% with Caco-2 cells, 2.7\% with HCT116, and $8.4 \%$ with HT-29 cells at a concentration of $4.8 \mathrm{mg} / \mathrm{mL}$ of yerba mate extract. The effect was less prominent on the NCM460 cell line where the viability of cells at the same concentration was $65.2 \%$. Yerba mate extract also showed concentration-dependent anti-proliferative effects as determined by the WST-1 proliferation kit. IC50 values ranged between $0.22-0.69 \mathrm{mg} / \mathrm{mL}$ at $24 \mathrm{hr}$ for cell lines tested. To study whether cell death was due to apoptosis, Caco-2 cells were stained with Annexin V-FITC assay and an increase in the percentage of late apoptotic Caco-2 cells was observed with yerba mate extract at $0.6-4.8 \mathrm{mg} / \mathrm{mL}$. Cell cycle analysis using DNA content by flow cytometry showed an increase in the percentage of Caco-2 cells in the subG0/G1 phase and the G0/G1 phase after treatment with $2.4 \mathrm{mg} / \mathrm{mL}$ extract. Collectively, our data suggest that yerba mate aqueous extract exhibits an anti-proliferative effect on tested cell lines by inducing apoptosis.

Conclusions: Yerba mate aqueous extract exhibits a strong anti-proliferative activity against adenocarcinoma cell lines studied and constitutes a promising functional food adjuvant to anti-cancer therapy. Further work is needed to identify active components and mechanisms of action.

Keywords: Aqueous extract, yerba mate, anti-proliferative activity, adenocarcinoma cell lines

CFFC 2021. This is an Open Access article distributed under the terms of the Creative Commons Attribution 4.0 License (http://creativecommons.org/licenses/by/4.0)

\section{BACKGROUND}

Traditional medicine is the predominant healthcare practice used by $80 \%$ of the world's population [1]. Throughout human history, people depended on herbal medicine to treat many diseases. The main limitation of herbal medicine is proper identification of active compounds and the absence of quality control [2]. Beverages such as coffee and tea have been extensively studied due to their high rate of consumption. Their secondary metabolites exhibit many biological activities. Yerba mate is among the most widely consumed beverages after tea and coffee.

Yerba mate (Ilex paraguariensis) is a South American dioecious tree that can reach up to 15 meters in height. It is mostly found in South America (south of Brazil, Paraguay, Uruguay and north of Argentina). It is also widely consumed in Lebanon and Syria within the Druze community. The dried leaves and branches of yerba mate are prepared as a tea. The major bioactive molecules in yerba mate are polyphenols such as caffeoyl derivatives, xanthines, saponins, rutin, quercetin and kaempferol [3]. Yerba mate extracts have higher polyphenolic levels than green tea extracts and have the same level as red wine [4]. Polyphenols are correlated with antioxidant activity, anti-cancer activity [5], antibacterial activity [6], and different health benefits [7]. Case studies have shown that diets rich in fruits and vegetables are inversely correlated with cancer incidence especially gastro-intestinal tract cancers [8-9]. Caffeic acid phenethyl ester was found to inhibit the development 
of ovarian cancer [10] and caffeic acid triggers apoptosis in human tongue squamous cell carcinoma [11].

Different studies correlate strong antioxidant activity with strong anti-cancerous activity. In a case study in Uruguay, healthy men and women diagnosed with breast cancer were given a questionnaire that focused on Body Mass Index (BMI), food intake (vegetables, fruits, red meat, chicken, and fish), tea intake and yerba mate intake. Results show a negative correlation between daily yerba mate intake and breast cancer [12-13]. In another study, high yerba mate intake had a significant inverse correlation with colorectal cancer onset [14]. Conversely, other studies associate yerba mate intake with an increase of incidence of different types of cancer such as oral, esophageal and oropharyngeal [15-16]. However, a previous study has attributed the high temperature of yerba mate at the time of consumption with oral carcinoma [17].

Colorectal cancer is the third most common type of cancer and the second most important cause of cancer-associated deaths worldwide [18]. Yerba mate saponins were tested on human colon cancer cells to evaluate their potential role in cell cycle arrest. Ursolic acid and dicaffeoylquinic acids show a strong anti-proliferative activity on HT-29 and RKO colon cancer cell lines [19-20]. Yerba mate aqueous extract showed strong cytotoxic and anti-proliferative activities on HT-29 and Caco-2 cell lines in a concentration dependent manner [21]. The extract also inhibited cell proliferation in colorectal cancer cell lines CT26 and COLO 205 [22]; however, it had no activity against adherent epithelial liver hepatocarcinoma cell line, HepG2 [23].
The aim of this study is to evaluate the anticancer activity of aqueous yerba mate extract on various human colorectal cell lines: Caco-2, HT-29, and HCT116 as well as on the non-tumorigenic human colon epithelial cell line NCM460. Most studies in literature focus on the methanolic extracts from yerba mate or their active compounds and their effects on different cancer cell lines. Other studies tested yerba mate infusions produced at $100^{\circ} \mathrm{C}$ $[21,24]$ or $95^{\circ} \mathrm{C}[22]$. This study is unique in that it mimics the actual preparation method of yerba mate, thus studying the extract as a functional food. Therefore, the anti-proliferative effect of the aqueous extract (prepared at $60-70^{\circ} \mathrm{C}$ ) on colorectal cancer cell lines was studied.

\section{METHODS}

Plant extract preparation: Commercial yerba mate package Amanda (AMA010; country of origin Argentina) was purchased from the market. Leaves and stems were dried under the hood for $24 \mathrm{hr}$ and then were ground using a Warren blender. The obtained powder was soaked with water $(1: 4 \mathrm{w} / \mathrm{v})$ and incubated in a water bath at $70^{\circ} \mathrm{C}$ for $2 \mathrm{hr}$. They were then passed through a gauze and filtered through Whatman paper. The filtrate was next centrifuged at 5,000 $\mathrm{G}$ for 30 minutes, dialyzed for 48 $\mathrm{hr}$ at $4^{\circ} \mathrm{C}$, and then concentrated in a speed vacuum at $50^{\circ} \mathrm{C}$. The extract was next stored at $4^{\circ} \mathrm{C}$. Dried yerba mate extract was dissolved in Dulbecco's modified eagle medium (DMEM; Sigma, Germany) to prepare a stock solution $(38.4 \mathrm{mg} / \mathrm{mL})$. Serial dilutions were prepared to obtain the desired treatment concentrations. 
Cell lines maintenance: The epithelial colorectal adenocarcinoma cell lines (Caco-2, HT-29, HCT116) and the non-tumorigenic human colon epithelial cell line (NCM460) were kindly provided by Dr. Marwan El-Sabban, American University of Beirut. Caco-2 cells were cultured in DMEM medium (Sigma, Germany), whereas HCT116 and HT-29 cells were cultured in RPMI 1640 medium (Sigma, Germany). Both media were supplemented with $1 \%$ L-Glutamine, $1 \%$ penicillin-streptomycin, and $10 \%$ fetal bovine serum (FBS; Gibco-BRL, Paisley, Scotland). NCM460 was cultured in M3 Base medium (INCELL, USA) supplemented with $1 \%$ penicillin-streptomycin and $10 \%$ FBS. The cells were incubated in a $5 \% \mathrm{CO}_{2}$ humidified incubator at $37^{\circ} \mathrm{C}$.

Trypan blue dye exclusion method: Caco-2, HT-29, HCT116, and NCM460 cells were plated at a density of $15 \times 10^{4}$ cells/well in 24 -well cell culture plates. After $24 \mathrm{hr}$, cells were incubated with different concentrations $(0.075,0.15,0.3,0.6,1.2,2.4$, and 4.8 $\mathrm{mg} / \mathrm{mL}$ ) of aqueous yerba mate extract for 24 and 48 $\mathrm{hr}$ at $37^{\circ} \mathrm{C}$ in a $5 \% \mathrm{CO}_{2}$ humidified incubator. The positive control consisted of media and $70 \%$ ethanol, whereas the negative control had only media. Following treatment, cells were washed with phosphate-buffered saline (PBS; Sigma, Germany), detached using StemPro accutase cell dissociation reagent (Thermo Fisher Scientific, USA), centrifuged, and cell viability was assayed using the trypan blue dye exclusion method [25]. Cell viability was calculated using the following formula: \% cell viability $=$ (number of live cells/ total number of cells) $* 100$. Results were expressed as the percentage of viable cells relative to untreated control.
Evaluation of cell proliferation: Cell proliferation was assayed using the Cell Proliferation Reagent WST-1 Assay (Roche Diagnostics, Germany). Cells were plated at a density of $1 \times 10^{4}$ cells/well in a 96-well cell culture plate and treated after $24 \mathrm{hr}$ with different concentrations $(0.075,0.15,0.3,0.6,1.2$, and 2.4 $\mathrm{mg} / \mathrm{mL}$ ) of aqueous yerba mate extract for 24,48 , and $72 \mathrm{hr}$ at $37{ }^{\circ} \mathrm{C}$ in a humidified $5 \% \mathrm{CO}_{2}$ incubator. After the respective time of incubation, $10 \mu \mathrm{L}$ of WST-1 reagent was added and incubated for $3 \mathrm{hr}$ following the manufacturer's directions. The absorbance of each well was measured using a microplate reader (Multiskan Ascent, Thermo Labsystems) at a wavelength of $490 \mathrm{~nm}$, with $680 \mathrm{~nm}$ set as a reference wavelength [26]. The results were expressed as percentage of control. As an internal positive control, cells were treated with $50 \%(\mathrm{v} / \mathrm{v}$ in culture medium) ethanol to induce cell death.

\section{Annexin V / propidum iodide (PI) staining and flow} cytometry analysis: Apoptosis and cell death were assayed using FITC Annexin V apoptosis detection kit II (BD Pharmingen, USA). Caco-2 cells were cultured in a 24 well plate at a density of $15 \times 10^{4}$ cells/well and treated with different concentrations $(0.075,0.15$, $0.3,0.6,1.2,2.4$, and $4.8 \mathrm{mg} / \mathrm{mL}$ ) of aqueous yerba extract for 24 or $48 \mathrm{hr}$. Negative controls consisted of cells in complete growth medium without the addition of extract, whereas the positive control consisted of cells in complete growth medium and treated with $\mathrm{H}_{2} \mathrm{O}_{2} \quad(300 \mu M)$ [27]. Following treatment, cells were washed with cold PBS, detached using accutase, centrifuged, and washed again with PBS. Cells were then resuspended in $100 \mu \mathrm{l}$ of Annexin V binding buffer (BD Biosciences, USA) and incubated with $5 \mu l$ Annexin $V$ - fluorescein 
isothiocynate (FITC) and $5 \mu \mathrm{PI}$ (BD Biosciences, USA) in the dark at room temperature for $15 \mathrm{~min}$. After incubation, cells were diluted with $400 \mu$ of binding buffer and subjected to flow cytometry analysis using FACSCalibur flow cytometer (BD Biosciences) [26]. A total of 10,000 cells were acquired with CellQuest Pro software. Cells were identified as viable (Annexin $\mathrm{V}^{-}$/ $\left.\mathrm{PI}^{-}\right)$, early apoptotic (Annexin $\left.\mathrm{V}^{+} / \mathrm{PI}^{-}\right)$, late apoptotic (Annexin $\mathrm{V}^{+} / \mathrm{PI}^{+}$) or dead (Annexin $\mathrm{V}^{-} / \mathrm{PI}^{+}$) [28-29].

Cell cycle analysis by flow cytometry: Caco-2 cells were cultured at a density of $0.7 \times 10^{6}$ cells/well in a 96-well plate and treated with different concentrations $(0.075,0.3$, and $2.4 \mathrm{mg} / \mathrm{mL})$ of aqueous yerba extract for 24 or 48 hr. Negative controls consisted of cells grown in complete growth medium without the addition of yerba mate extract. Following treatment, cells were washed with cold PBS, detached using accutase, centrifuged, resuspended in ice-cold PBS and fixed with $70 \%$ ethanol (ice-cold). Cells were then stored at $-20^{\circ} \mathrm{C}$ for $24 \mathrm{hr}$. Cell pellets were washed twice with ice-cold PBS, collected by centrifugation, and re-suspended in $500 \mu \mathrm{l}$ of propidium iodide ( $50 \mu \mathrm{g} / \mathrm{ml}$ diluted in PBS). After incubation with $\mathrm{PI}$ in the dark at room temperature for 30 mins. Cell cycle analysis was carried out using Guava InCyte software on Guava Easy Cyte 8 flow cytometer (Millipore, Germany) where 25,000 events per sample were collected.

Statistical analysis: Experiments were done in triplicates and repeated at least three times. Results are presented as mean \pm standard error of the mean (SEM). Data analyses were performed using GraphPad Prism version 9.0.0 (GraphPad Software, San Diego, CA, USA). Statistical significance for WST-1 assays was tested with one-way ANOVA. Two-way
ANOVA test was used for Trypan blue, apoptosis, and cell-cycle assays. The post-hoc Dunnet's multiple comparison test to compare the effect of each treatment dose with the untreated control was used for all assays. *: $P<0.05,{ }^{* *}: P<0.01, * * *: P<0.001$, $* * * *: P<0.0001$.

\section{RESULTS}

Effect of aqueous yerba mate extract on human colon cancer cell lines viability: Trypan blue stain can only penetrate dead cells; thus, it can be used to differentiate between viable and non-viable cells. Trypan blue assay was performed on all four cell lines (Caco-2, HT-29, HCT116, NCM460) after their treatment with increasing concentrations $(0.075$, $0.15,0.3,0.6,1.2,2.4$, and $4.8 \mathrm{mg} / \mathrm{mL}$ ) of aqueous yerba mate extract at 24 and $48 \mathrm{hr}$ (Figure 1). The viability of untreated control cells was considered as $100 \%$. Following $24 \mathrm{hr}$ treatment with $4.8 \mathrm{mg} / \mathrm{mL}$ Yerba mate aqueous extract, cell viability significantly $(P<0.0001)$ decreased to $19.7 \%$ with Caco-2 cells (Figure 1A), 2.7\% with HCT116 cells (Figure 1B), and 8.4\% with HT-29 cells (Figure $1 \mathrm{C}$ ), as compared to control cells. The effect was less prominent on NCM460 cells where the viability of cells at the same concentration was $65.2 \%$ (Figure 1D). A similar dose dependent effect $4.8 \mathrm{mg} / \mathrm{mL}$ yerba mate extract was observed post $48 \mathrm{hr}$ treatment where cell viability was significantly $(P<0.0001)$ decreased to $22.8 \%$ with Caco-2 cells (Figure 1A), 6.2\% with HCT116 (Figure 1B), 3.3\% with HT-29 (Figure 1C), and $48.1 \%$ with NCM460 (Figure 1D). The most prominent cytotoxic effect of yerba mate extract was on HCT116 and HT29 cell lines, while the least observed cytotoxic effect was on NCM460 cells (Figure 1). As a positive control, all cell lines were treated with $70 \%$ ethanol, and this resulted in $100 \%$ cell death (data not shown). 


\section{A}

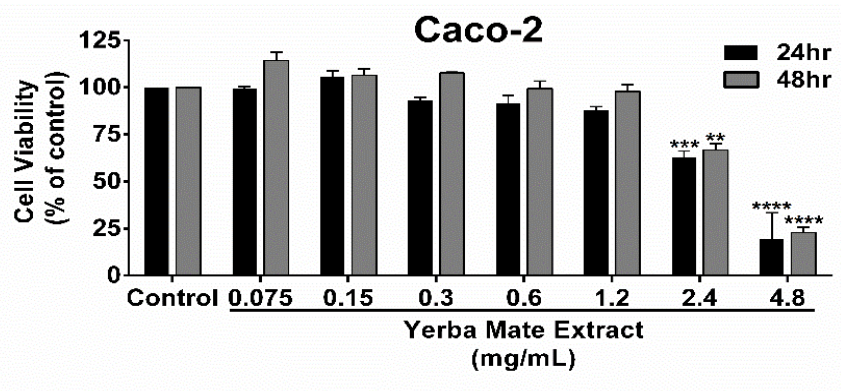

B
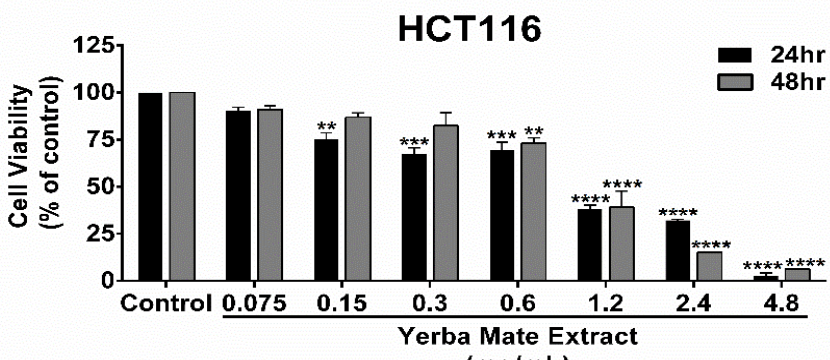
$(\mathrm{mg} / \mathrm{mL})$

C

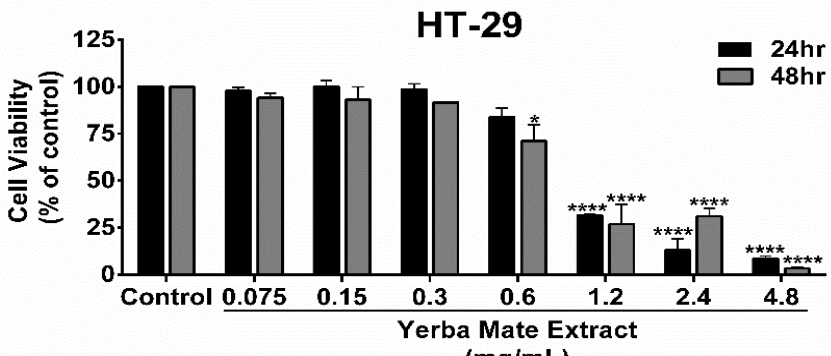
$(\mathrm{mg} / \mathrm{mL})$

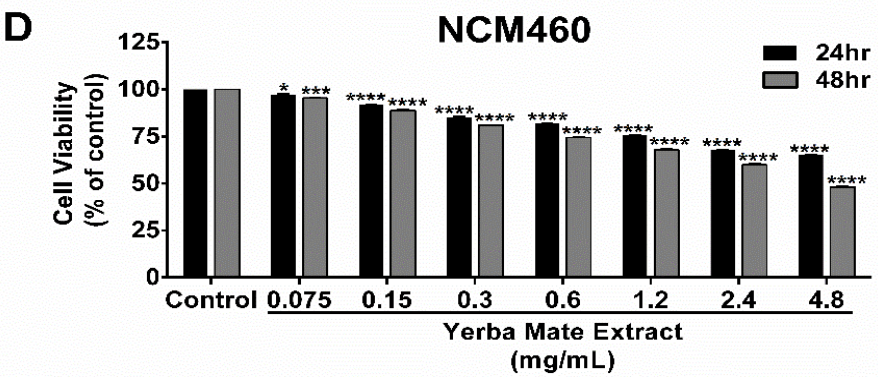

Figure 1.

Figure 1. Effect of aqueous yerba mate extract on the viability of different colon cancer cell lines. Cells were treated with increasing concentrations of yerba mate extract for 24 and $48 \mathrm{hr}$. Untreated cells cultured in complete growth medium alone served as a negative control (control). Cell viability was measured using the trypan blue assay. Yerba mate extract decreased the viability of (A) Caco-2, (B) HCT116, (C) HT-29 and (D) NCM460 cells in a dose dependent manner. Bar graphs indicate the percentage of viable cells relative to control. Results are presented as mean \pm standard error of the mean (SEM) of three separate experiments each performed at least in duplicate. ${ }^{*}: P<0.05,{ }^{* *}: P<0.01,{ }^{* * *}: P<0.001,{ }^{* * * *}: P<0.0001$ vs control at the same time point.

\section{Anti-proliferative activity of aqueous yerba mate} extract on human on colon cancer cell lines: The antiproliferative effect of different concentrations ( 0.075 , $0.15,0.3,0.6,1.2,2.4$, and $4.8 \mathrm{mg} / \mathrm{mL}$ ) of yerba mate extract against three human colon cancer lines (Caco-
2, HCT116, and HT-29) was studied using Wst-1 assay at three time points: 24, 48 and $72 \mathrm{hr}$ (Figure 2). Aqueous yerba mate extract showed a strong antiproliferative effect on Caco-2, HCT116, and HT29 cell lines that was concentration and time dependent. 


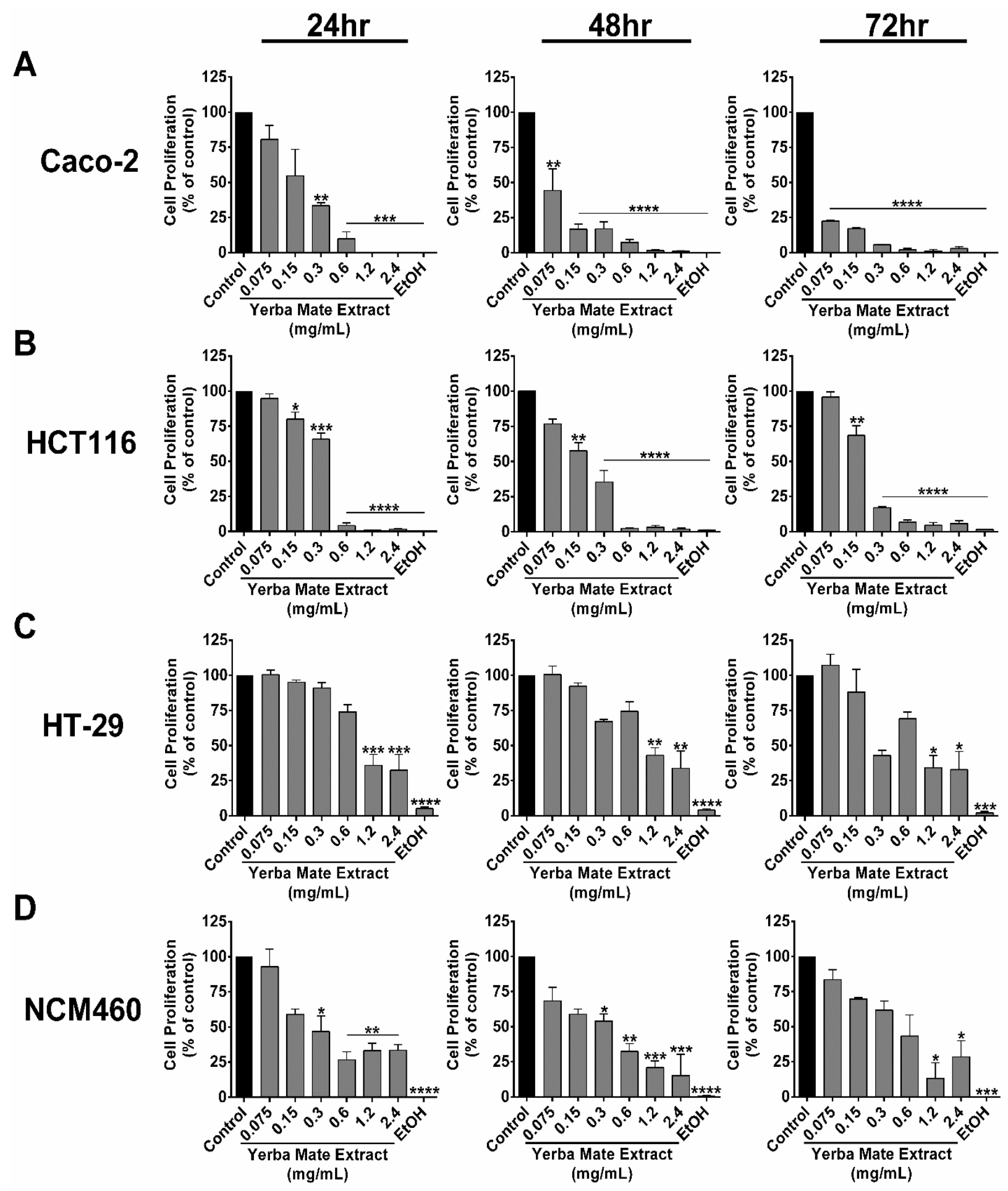

Figure 2.

Figure 2. The anti-proliferative activity of aqueous yerba mate extract on different colon cancer cell lines. Cell lines were treated with increasing concentrations of yerba mate extract for 24,48 and $72 \mathrm{hr}$. Untreated cells cultured in complete growth medium alone served as a negative control (control). Cells treated with $50 \%$ ethanol (EtOH) served as a positive control for the inhibition of cell proliferation. Cell proliferation was measured using WST-1 assay. Yerba mate extract decreased the proliferation of (A) Caco-2, (B) HCT116, (C) HT-29 and (D) NCM460 cells at a concentration and time dependent manner. $\mathrm{IC}_{50}$ (concentration at which $50 \%$ of cells died) was calculated. Bar graphs show the percentage of proliferating cells relative to control. Results are presented as mean \pm standard error of the mean (SEM) of three separate experiments each performed at least in triplicate. ${ }^{*}: P<0.05,{ }^{* *}: P<0.01,{ }^{* * *}: P<0.001,{ }^{* * * *}: P<0.0001$ vs control. 
The strongest effect was on Caco-2 and HCT116 cells. For Caco-2, the IC50 values were $0.22 \mathrm{mg} / \mathrm{mL}$ at $24 \mathrm{hr}$, $0.06 \mathrm{mg} / \mathrm{mL}$ at $48 \mathrm{hr}$, and $0.02 \mathrm{mg} / \mathrm{ml}$ at $72 \mathrm{hr}$ (Figure 2A). IC50 values for HCT116 were $0.35 \mathrm{mg} / \mathrm{mL}$ at 24 $\mathrm{hr}, 0.19 \mathrm{mg} / \mathrm{mL}$ at $48 \mathrm{hr}$, and $0.18 \mathrm{mg} / \mathrm{mL}$ at $72 \mathrm{hr}$ (Figure 2B). While the IC50 values for HT-29 were

\section{Effect of aqueous yerba mate extract apoptosis of} Caco-2 cells: To further understand the antiproliferative mechanism of yerba mate extract, the Annexin V-FITC/PI assay was performed only on Caco2 cells since IC50 values for yerba mate extract against Caco-2 cells were significantly lower than those against other studied cell lines. Various concentrations of aqueous yerba mate extract $(0.075$, $0.15,0.3,0.6,1.2,2.4$, and $4.8 \mathrm{mg} / \mathrm{mL}$ ) were tested on Caco- 2 cells for 24 and $48 \mathrm{hr}$. At both time points and in a dose dependent manner, treatment (starting at $0.6 \mathrm{mg} / \mathrm{mL}$ ) of Caco-2 cells with yerba mate extract induced a significant decrease in the percentage of viable cells in comparison with that of control untreated cells (Figure 3). Caco-2 cells treated with yerba mate extract at concentrations of $0.6-4.8$ $\mathrm{mg} / \mathrm{mL}$ for $24 \mathrm{hr}$ demonstrated significantly elevated percentages of late apoptotic cells (34-42\%) as compared to that of control untreated cells $(10 \%)$, suggesting that yerba mate extract induced apoptosis (Figure 3). A similar pattern was noted at $48 \mathrm{hr}$; however, the increase in the percentage of late apoptotic cells came out to be statistically significant only following treatment with $1.2 \mathrm{mg} / \mathrm{mL}$ of yerba mate extract (Figure 3). There were no significant differences in the percentages of early apoptotic cells between control untreated cells and yerba matetreated cells at all tested concentrations at $24 \mathrm{hr}$. In contrast, there was a trend towards increased
$0.69 \mathrm{mg} / \mathrm{ml}$ at $24 \mathrm{hr}, 0.77 \mathrm{mg} / \mathrm{mL}$ at $48 \mathrm{hr}$, and 0.17 $\mathrm{mg} / \mathrm{mL}$ at $72 \mathrm{hr}$ (Figure 2C). Most concentrations of yerba mate extract demonstrated a significant decrease in NCM460 proliferations at both 24 and 48 $\mathrm{hr}$,except at concentrations lower than $0.3 \mathrm{mg} / \mathrm{mL}$ (Figure 2D).

percentages of early apoptotic cells following $48 \mathrm{hr}$ treatment with yerba mate extract. Moreover, exposure of Caco-2 cells to different concentrations of yerba mate extract resulted in an increase in the percentage of dead cells after 24 and $48 \mathrm{hr}$ treatment with respect to the untreated control, but this did not achieve statistical significance (Figure 3).

\section{Effect of aqueous yerba mate extract on cell cycle} progression of Caco-2 cells: To examine if the growth inhibitory effects of aqueous yerba mate extract is due to growth arrest, three concentrations of the extract $(0.075,0.3$, and $2.4 \mathrm{mg} / \mathrm{mL})$ were tested on Caco-2 cells for $48 \mathrm{hr}$ then examined for cell cycle progression using flow cytometry. We observed a trend towards an increase in the cell population present in the sub G0/G1 phase following treatment of Caco-2 cells with $2.4 \mathrm{mg} / \mathrm{mL}$ (17.5\%) of yerba mate extract in comparison to control untreated cells (7.7\%) (Figure 4). An increase in the percentage in the G0/G1 phase was also observed with $2.4 \mathrm{mg} / \mathrm{mL}(55.4$ $\%)$ relative to control (46.9\%). In addition, the population of cells in the S phase decreased with 2.4 $\mathrm{mg} / \mathrm{mL}$ yerba mate treatment $(18.8 \%)$ compared to control (13.2\%). Finally, the percentage of yerba mate-treated $(2.4 \mathrm{mg} / \mathrm{mL}$ ) cells in $\mathrm{G} 2 / \mathrm{M}$ phase fell from 26.5 to $13.8 \%$ compared to control untreated cells (Figure 4). 
Annexin $/ \mathrm{PI}^{-}$(Viable Cells)

Annexin ${ }^{+} / \mathrm{PI}^{-}$(Early Apoptotic Cells)
Annexin ${ }^{+} / \mathrm{PI}^{+}$(Late Apoptotic Cells)

Annexin $/ \mathrm{PI}^{+}$(Dead Cells)
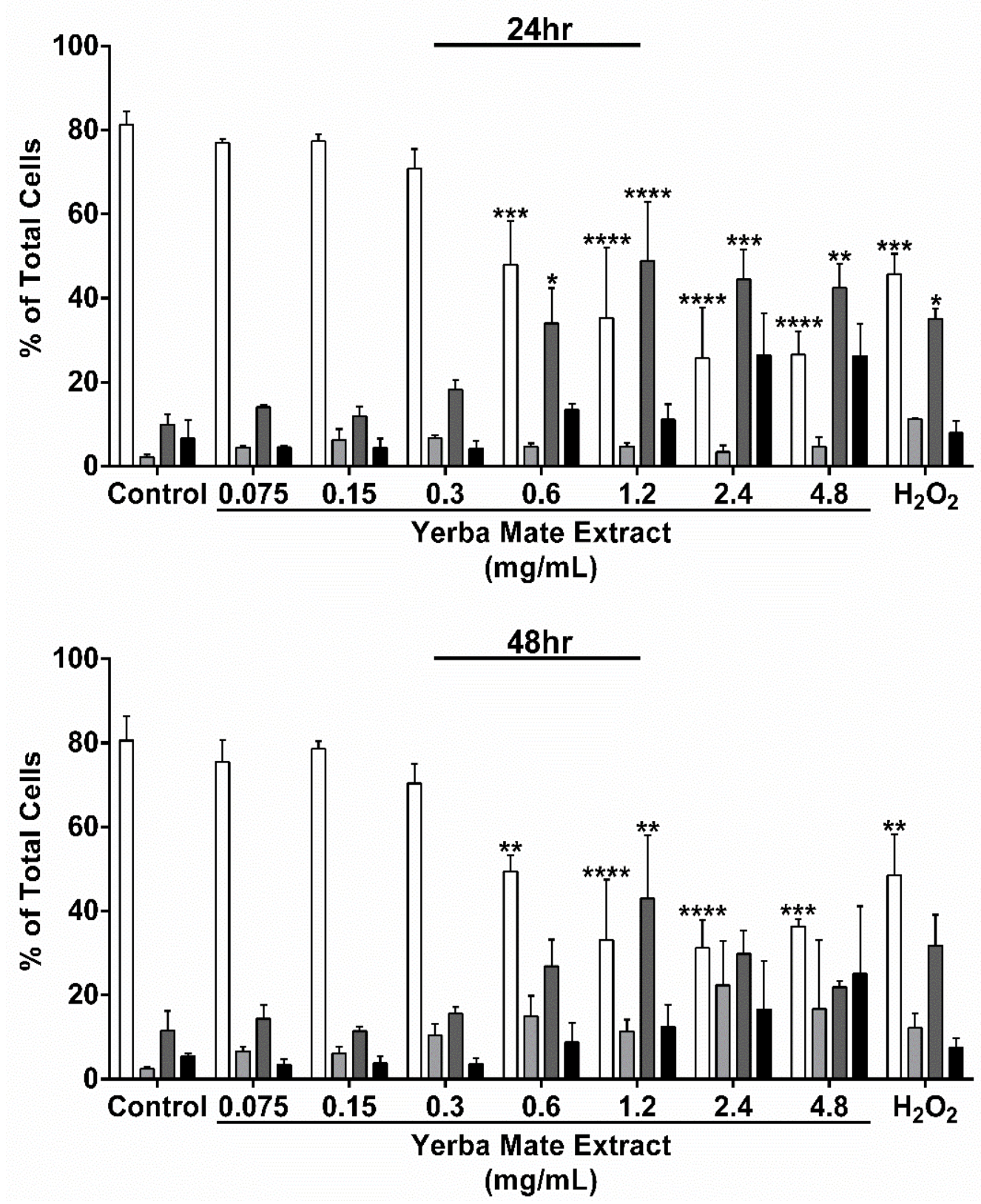

Figure 3.

Figure 3. Effect of various concentrations of aqueous yerba mate extract on apoptosis of Caco-2 cell. Caco-2 cells were treated with different concentrations of yerba mate extract for 24 and $48 \mathrm{hr}$. Untreated cells cultured in growth medium alone served as a negative control (control). Cells treated with $300 \mu \mathrm{M} \mathrm{H}_{2} \mathrm{O}_{2}$ served as a positive control for the induction of apoptosis. Cells were then stained with Annexin V-FITC and propidium iodide (PI) and analyzed by flow cytometry. Bar graphs show the percentage of different cell populations: Annexin $/ \mathrm{PI}^{-}$(live cells), Annexin $/ \mathrm{PI}^{-}$ (early apoptotic cells), Annexin $/ \mathrm{PI}^{+}$(late apoptotic cells) and Annexin $/ \mathrm{PI}^{+}$(dead cells). Results are presented as mean \pm standard error of the mean (SEM) of three separate experiments each performed at least in triplicate. *: $P<0.05$, **: $P<0.01,{ }^{* * *}: P<0.001,{ }^{* * *}: P<0.0001$ vs control. 


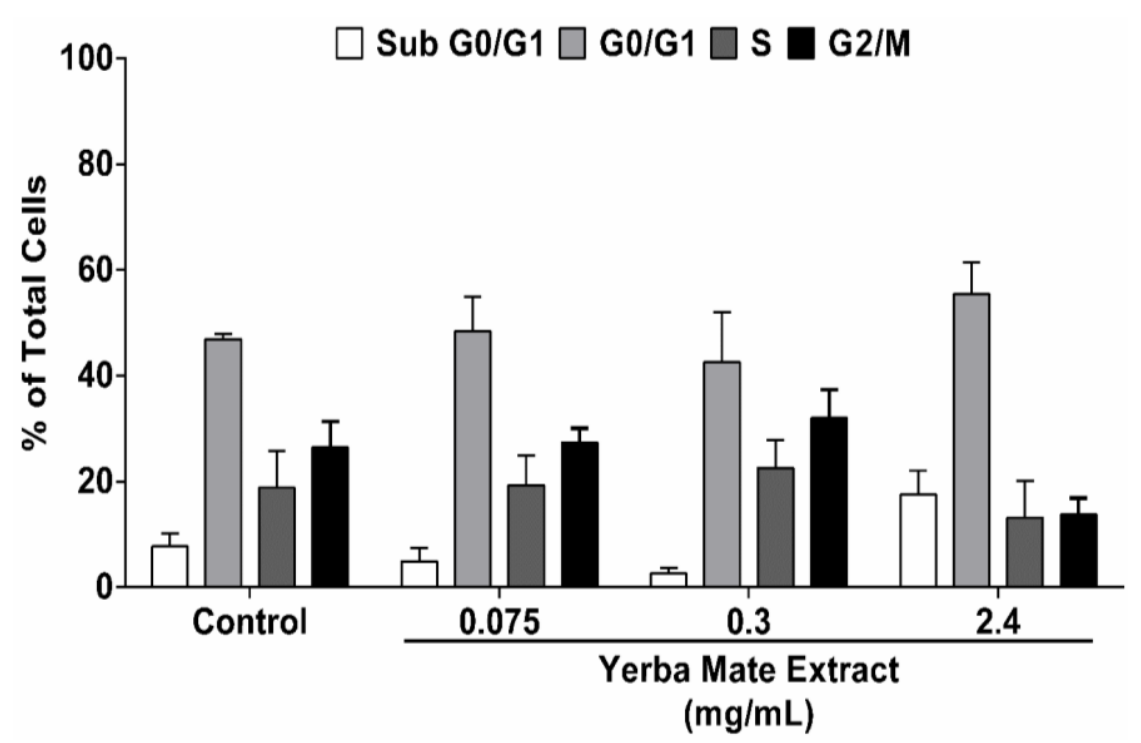

Figure 4.

Figure 4. Effect of aqueous yerba mate extract on cell cycle progression of Caco-2 cells. Caco-2 cells were treated with different concentrations of yerba mate extract for $48 \mathrm{hr}$. Untreated cells cultured in growth medium alone served as a negative control (control). Cells were permeabilized, stained with propidium iodide and analyzed by flow cytometry. Bar graphs show the percentage of cells in each phase of the cell cycle. Results are presented as mean \pm standard error of the mean (SEM) of three separate experiments.

\section{DISCUSSION}

Herbal infusions have been used historically to treat a variety of diseases. Screening herbal extracts for anticancer properties has gained increasing popularity with the need for novel drugs and treatments. It has been previously reported that a third of cancer patients in Europe use complementary and alternative medicine [30]. Yerba mate is an herbal tea that is rich in polyphenols and that has attracted increasing interest. Due to its consumption method that requires the continuous addition of hot water, it yields an average of $520 \mathrm{mg}$ of caffeine per 1 liter of yerba mate consumed [31]. Yerba mate's caffeine, caffeic acid, and chlorogenic acid content exceed the intake recorded in the literature for other beverages.

In this study, the anti-cancer effect of aqueous yerba mate extract was tested against three colorectal cancer cell lines (Caco-2, HT-29, HCT116) and a non-tumorigenic colon cell line NCM460. The extract was prepared according to method of consumption and concentrations studied correspond to consumed values [31-32]. A significant decrease in viability was observed using Trypan Blue assay with all three tested colorectal cancer cell lines at concentrations of $2.4 \mathrm{mg} / \mathrm{mL}$ and $4.8 \mathrm{mg} / \mathrm{mL}$ yerba mate extract at 24 and $48 \mathrm{hr}$. Anti-proliferative effects were also observed with IC50 ranging between 0.22$0.69 \mathrm{mg} / \mathrm{ml}$ at $24 \mathrm{hr}, 0.06-0.77 \mathrm{mg} / \mathrm{ml}$ at $48 \mathrm{hr}$, and 0.02-0.18 at $72 \mathrm{hr}$. Previous studies show antiproliferative activity of yerba mate extracts with IC50 $0.22 \mathrm{mg} / \mathrm{mL}$ for Caco-2 and HT-29 cells at $48 \mathrm{hr}$ [21] and IC50 values of $0.25 \mathrm{mg} / \mathrm{mL}$ for CT26 and 0.46 $\mathrm{mg} / \mathrm{mL}$ for COLO 205 cells at $72 \mathrm{hr}$ [22]. Values of IC50 differ due to differences in method of extract preparation. Derivatives from yerba mate extract, such as caffeoylquinic acid, also exhibit antiproliferative activity on human colon cancer cell line through apoptosis [20].

Caco-2 and HCT116 cells were more susceptible to yerba mate extract, in this study, than HT-29 or 
NMC460. Berg et al. (2017) classified 34 colorectal cancer cell lines according to their molecular characteristics into either colon-like or undifferentiated cell lines [33]. Interestingly, Caco-2 and HCT116 were categorized as undifferentiated and HT-29 as colon-like. The undifferentiated cell lines originate from tumors with inferior prognosis in comparison to colon-like cells. Therefore, it would be expected that among the three studied colorectal cancer cell lines, the IC50 values in the colon-like HT29 cells would be the closest to the values seen for NCM460, a non-tumorigenic colon cell line. Further studies would be required to investigate the mechanism that potentiates differentiated or colonlike cell lines to be more resistant to yerba mate extract than poorly or undifferentiated colorectal cancer cell lines.

It is not clear in literature whether the nontumorigenic human colon cell line NCM460 can be used as a control. NCM460 was previously described as a control cell line in anti-cancer strategies against colon cancer since NCM460 cells uses $40 \%$ less glucose and shows an active tricarboxylic acid cycle contrary to the reported metabolic profile of cancer cells [34]. NCM460 is also considered as a control model in a study where $P$. anaerobius induces the proliferation of Caco-2 and HT-29 cells [35]. However, Zeng et al. (2017) show that butyrate inhibits the proliferation of both HCT116 and NCM460 cells but with less death in NCM460 [36]. The latter results correspond to the effect of the aqueous yerba mate extract on NCM460 cells reported in this study.

To further understand the mechanism of antiproliferative activity of the aqueous yerba mate extract, Annexin V-FITC assay was studied on the cell line with the lowest IC50 obtained. A significant decrease in the number of viable cells was observed in Caco- 2 cells that was time and dose dependent. An increase in the percentage of late apoptotic Caco-2 cells was observed following 24 and $48 \mathrm{hr}$ treatment with yerba mate extract $(0.6-4.8 \mathrm{mg} / \mathrm{mL})$; whereas no differences were noted in the percentage of early apoptotic cells post treatment. In a previous study, yerba mate infusions induced $30 \%$ and $28 \%$ of early apoptotic cells in SW620 and SW480 cells respectively at $48 \mathrm{hr}$ [37]. Further analysis was done by performing cell cycle analysis on Caco-2 cell lines using flow cytometry. Treatment with $2.4 \mathrm{mg} / \mathrm{mL}$ of aqueous yerba mate extract increased the percentage of Caco2 cells in the subG0/G1 phase (17.5\%) compared to the control $(7.7 \%)$ at $48 \mathrm{hr}$. Moreover, aqueous extract of Ilex paraguariensis are reported to increase the SubG0/G1 percentage by $16 \%$ in SW620 and by $38 \%$ in SW480 cells [37]. Likewise, our aqueous yerba mate extract also enhanced the G0/G1 phase. One of the main characteristics of apoptosis is nuclear fragmentation and while the SubG1 peak could represent apoptotic cells, necrotic cells could also contribute to this peak [38]. Furthermore, cells could go through apoptosis at the $\mathrm{S}$ or G2/M phases and therefore, they will not be observed in the SubG1 peak. It has been suggested that the anti-proliferative activity of the yerba mate extract on CT26 and COLO 205 cells was through induction of apoptosis [22]. More work is needed to understand the mechanism of action of yerba mate extract on different cell lines studied.

\section{CONCLUSIONS}

In summary, the aqueous yerba mate extract prepared with conditions that mimic that of consumption, exhibit a strong anti-proliferative activity against the adenocarcinoma cell lines studied. Thus, it is of interest as a functional food or to be used as an adjuvant to anti-cancer therapy. Further experiments should be conducted to evaluate active 
biological components of yerba mate and to further understand its mechanism of action.

List of Abbreviations: DMEM: Dulbecco's Modified Eagle Media, FBS: Fetal Bovine Serum, IC50: Halfmaximal Inhibitory Concentration, LDH: Lactate Dehydrogenase, PBS: Phosphate Buffer Saline, PI: Propidium lodide, WST-1: 2-(3-lodophenyl)-3-(4Nitrophenyl)-5-(2,4-Disulfophenyl)-2H-Tetrazolium Monosodium Salt.

Author Contributions: Conceptualization and Methodology: M.E-S and R.A-M; Formal analysis: A.J.S., L.O., M.C., and R.G., and S.B.; Conducted the research: A.J.S., L.O., M.C., and R.G.; Resources: M.ES and R.A-M; Writing-original draft: A.J.S., L.O., M.C., and R.G.; Writing - review and editing, S.B. and R.AM; Supervision and Project administration: R.A-M. All authors read and approved the final version of the manuscript.

Competing Interests: The authors have declared that no competing interests exist.

Acknowledgments and Funding: This research did not receive any specific grant from funding agencies in the public, commercial, or not-for-profit sectors.

\section{REFERENCES}

1. Ekor $M$ : The growing use of herbal medicines: issues relating to adverse reactions and challenges in monitoring safety. Front Pharmacol 2014. 4:177.

2. Balekundri A, Mannur V: Quality control of the traditional herbs and herbal products: a review Future J Pharm Sci 2020. 6:67.

3. Burris KP, Harte FM, Michael Davidson P, Stewart CN, Zivanovic S: Composition and bioactive properties of Yerba Mate (Ilex paraguariensis A. St.-Hil.): A review. Chil J Agric Res 2012. 72:268-274.

4. Gugliucci A, Bastos DH, Schulze J, Souza MF: Caffeic and chlorogenic acids in Ilex paraguariensis extracts are the main inhibitors of AGE generation by methylglyoxal in model proteins. Fitoterapia 2009. 80:339-344.

5. Yang CS, Landau JM, Huang MT, Newmark HL: Inhibition of carcinogenesis by dietary polyphenolic compounds. Annu Rev Nutr 2001. 21:381-406.

6. Fayad E, El-Sawalhi S, Azizi L, Beyrouthy M, AbdelMassih RM: Yerba Mate (Ilex paraguariensis) a potential food antibacterial agent and combination assays with different classes of antibiotics. LWT-Food Sci Technol, 2020. 125:109267.

7. Nardini M, Natella F, Scaccini C: Role of dietary polyphenols in platelet aggregation. A review of the supplementation studies. Platelets 2007. 18:224-243.

8. Benetou V, Orfanos P, Lagiou P, Trichopoulos D, Boffetta $P$, Trichopoulou A: Vegetables and fruits in relation to cancer risk: evidence from the Greek EPIC cohort study. Cancer Epidemiol Biomarkers Prev 2008. 17:387-392.

9. Wang $\mathrm{H}$, Khor TO, Shu L, Su ZY, Fuentes F, Lee JH, Kong AN: Plants vs. cancer: a review on natural phytochemicals in preventing and treating cancers and their druggability. Anticancer Agents Med Chem 2012. 12:1281-1305

10. Liu GL, Han NZ, Liu SS: Caffeic acid phenethyl ester inhibits the progression of ovarian cancer by regulating NF-кB signaling. Biomed Pharmacother 2018. 99:825831.

11. Celinska-Janowicz K, Zareba I, Lazarek U, Teul J, Tomczyk M, Palka J, Miltyk W: Constituents of Propolis: Chrysin, Caffeic Acid, p-Coumaric Acid, and Ferulic Acid Induce PRODH/POX-Dependent Apoptosis in Human Tongue Squamous Cell Carcinoma Cell (CAL-27). Front Pharmacol 2018. 9:336.

12. Ronco AL, Stefani ED, Mendoza B, Deneo-Pellegrini $H$, Vazquez A, Abbona E: Mate Intake and Risk of Breast Cancer in Uruguay: a Case- Control Study. Asian Pac J Cancer Prev 2016. 17:1453-1461.

13. Ronco AL, Espinosa E, Calderon JM, Lasalvia- Galante E, De Rosa A, Sanchez G: 'Mate' Intake, Hormone-Based Risk Factors and Breast Cancer: a Case-Control Study. Asian Pac J Cancer Prev 2017. 18:941-948.

14. Ronco AL, De Stefani E, Lasalvia-Galante E, Mendoza B, Vazquez A, Sanchez G: Hot infusions and risk of colorectal cancer in Uruguay: a case-control study. Eur J Clin Nutr 2017. 71:1429-1436.

15. Goldenberg D, Golz A, Joachims HZ: The beverage mate: a risk factor for cancer of the head and neck. Head Neck 2003. 25:595-601.

16. Loria D, Barrios E, Zanetti R: Cancer and yerba mate consumption: a review of possible associations. Rev Panam Salud Publica 2009. 25:530-539. 
17. Deneo-Pellegrini H, De Stefani E, Boffetta P, Ronco AL, Acosta G, Correa P, Mendilaharsu M: Mate consumption and risk of oral cancer: Case-control study in Uruguay. Head Neck 2013. 35:1091-1095.

18. Sung $H$, Ferlay J, Siegel RL, Laversanne $M$, Soerjomataram I, Jemal A, Bray F: Global Cancer Statistics 2020: GLOBOCAN Estimates of Incidence and Mortality Worldwide for 36 Cancers in 185 Countries. CA Cancer J Clin 2021. 71:209-249.

19. Puangpraphant $S$, Berhow MA, Vermillion K, Potts G, Gonzalez de Mejia E: Dicaffeoylquinic acids in Yerba mate (Ilex paraguariensis St. Hilaire) inhibit NF-kappaB nucleus translocation in macrophages and induce apoptosis by activating caspases- 8 and -3 in human colon cancer cells. Mol Nutr Food Res 2011. 55:15091522.

20. Puangpraphant S, Berhow MA, De Mejia E: Yerba mate (Ilex paraguariensis St. Hilaire) saponins inhibit human colon cancer cell proliferation. Hispanic Foods: Chemistry and Bioactive Compounds. Volume 1109. Edited by Tunick MH and de Mejía EG. American Chemical Society; 2012. 307-321.

21. de Mejía EG, Song YS, Heck Cl, Ramírez-Mares M: Yerba mate tea (Ilex paraguariensis): Phenolics, antioxidant capacity and in vitro inhibition of colon cancer cell proliferation. 2010. 2:23-34.

22. Garcia-Lazaro RS, Lamdan H, Caligiuri LG, Lorenzo N Berengeno AL, Ortega HH, Alonso DF, Farina HG: In vitro and in vivo antitumor activity of Yerba Mate extract in colon cancer models. J Food Sci 2020. 85:2186-2197.

23. Boaventura BCB, Amboni RDdMC, da Silva EL, Prudencio ES, Di Pietro PF, Malta L G, Polinati RM, Liu RH: Effect of in vitro digestion of yerba mate (Ilex paraguariensis $\mathrm{A}$. St. Hil.) extract on the cellular antioxidant activity, antiproliferative activity and cytotoxicity toward HepG2 cells. Food Res Int 2015. 77:257-263.

24. Puangpraphant $S$, de Mejia EG: Saponins in yerba mate tea (Ilex paraguariensis A. St.-Hil) and quercetin synergistically inhibit iNOS and COX-2 in lipopolysaccharide-induced macrophages through NFkappa-B pathways. J Agric Food Chem 2009. 57:88738883.

25. Strober W: Trypan Blue Exclusion Test of Cell Viability. Curr Protoc Immunol 2015, 111:A3.B.1-A3.B.3.

26. Abdel-Massih RM, Fares R, Bazzi S, El-Chami N, Baydoun E: The apoptotic and anti-proliferative activity of Origanum majorana extracts on human leukemic cell line. Leuk Res 2010. 34:1052-1056.

27. Xiang J, Wan C, Guo R, Guo D: Is Hydrogen Peroxide a Suitable Apoptosis Inducer for All Cell Types? Biomed Res Int 2016. 2016:7343965.
28. Vermes I, Haanen C, Steffens-Nakken H, Reutelingsperger C: A novel assay for apoptosis. Flow cytometric detection of phosphatidylserine expression on early apoptotic cells using fluorescein labelled Annexin V. J Immunol Methods 1995. 184:39-51.

29. Del Bino G, Darzynkiewicz Z, Degraef C, Mosselmans R, Fokan D, Galand P: Comparison of methods based on annexin-V binding, DNA content or TUNEL for evaluating cell death in HL-60 and adherent MCF-7 cells. Cell Prolif 1999. 32:25-37.

30. Molassiotis A, Fernandez-Ortega P, Pud D, Ozden G, Scott J A, Pantelil V, Patiraki E. Use of complementary and alternative medicine in cancer patients: a European survey. Ann Oncol 2005. 16:655-663.

31. Mazzafera P: Maté drinking: caffeine and phenolic acid intake. Food Chem 1997. 60:67-71.

32. Bracesco N, Sanchez AG, Contreras V, Menini T, Gugliucci A: Recent advances on Ilex paraguariensis research: minireview. J Ethnopharmacol 2011. 136:378384.

33. Berg KCG, Eide PW, Eilertsen IA, Johannessen B, Bruun J, Danielsen SA, Bjørnslett M, Meza-Zepeda LA, Eknæs M, Lind GE, Myklebost O, Skotheim RI, Sveen A, Lothe RA: Multi-omics of 34 colorectal cancer cell lines - a resource for biomedical studies. Mol Cancer 2017. 16:116.

34. Alcarraz-Vizan G, Sanchez-Tena S, Moyer MP, Cascante M: Validation of NCM460 cell model as control in antitumor strategies targeting colon adenocarcinoma metabolic reprogramming: trichostatin $A$ as a case study. Biochim Biophys Acta 2014. 1840:1634-1639.

35. Long X, Wong CC, Tong L, Chu ESH, Ho Szeto C, Go MYY, $\mathrm{Yu} \mathrm{J}$ : Peptostreptococcus anaerobius promotes colorectal carcinogenesis and modulates tumour immunity. Nat Microbiol 2019. 4:2319-2330.

36. Zeng H, Taussig DP, Cheng WH, Johnson LK, Hakkak R: Butyrate Inhibits Cancerous HCT116 Colon Cell Proliferation but to a Lesser Extent in Noncancerous NCM460 Colon Cells. Nutrients 2017. 9:25.

37. Pérez JM, Maldonado ME, Rojano BA, Alzate F, Sáez J, Cardona W: Comparative antioxidant, antiproliferative and apoptotic effects of Ilex laurina and Ilex paraguariensis on colon cancer cells. Trop J Pharm Res 2014. 13:1279-1286.

38. Gamet-Payrastre L, Li P, Lumeau S, Cassar G, Dupont M, Chevolleau S, Terce F: Sulforaphane, a naturally occurring isothiocyanate, induces cell cycle arrest and apoptosis in HT29 human colon cancer cells. Cancer Res 2000. 60:1426-1433. 